\title{
Coding Labour
}

\begin{tabular}{c}
\hline ANTHONY MCCOSKER \\
SWINBURNE UNIVERSITY \\
AND \\
ESTHER MILNE \\
SWINBURNE UNIVERSITY \\
\hline
\end{tabular}

Code is an elusive object of analysis for media and cultural studies. It is perhaps already over fetishised, and often thought of as the exclusive property of computer science, engineering or bioinformatics. Of course, code has come to name a diverse range of objects and processes. ${ }^{1}$ For instance, while it has become synonymous with computer languages, the commands that put information technologies to work, code is more than software. ${ }^{2}$ Code encompasses the laws that regulate human affairs and the operation of capital, behavioural mores and accepted ways of acting, but it also defines the building blocks of life as DNA. In this way code refers to the operational technical systems and instructions that configure and govern machines as well as bodies, and also designates the cultural techniques and protocols that affect and are affected by social relations.

What continues to make code such a pressing topic for exploration and analysis is that in each of these domains it has become central to the question of what it means to live digitally. The articles comprising the 'coding labour' section of this issue are concerned in different ways with the diffusion of code across the material 
contexts of everyday life, in the objects and tools of our mediation, in the systems and practices of organisation and cultural production and, ultimately, in the material conditions of labour. As well as introducing these articles, we wish to explore the increasingly familiar connections between code and labour, with particular attention to the codification of affect, as intensity, through the technologies and practices of management within the contemporary work organisation. ${ }^{3}$ Our aim here is not only to reaffirm the complexities of code for emerging fields such as software studies, but to also consider some of the ways code moves between media, software and computation, through labour into social life and global capitalism. In the following sections we illustrate the everyday work of code within the contemporary organisation, in the 'grey literature' of forms, spreadsheets and workload models, and in the routinisation of the organisational crisis. These are key sites and practices through which code and labour interconnect.

As part of a recent 'material turn' in media and cultural studies, attention to code follows an emerging interest in the proliferation of devices and media platforms as they figure the conditions of our communicative, cultural, political and economic formations. Those at the forefront of software studies have made what may be a significant political shift by expanding beyond the technical understanding of code as a rule that transforms a message from one symbolic form into another, to incorporate, as Adrian Mackenzie puts it, 'all the forms of contestation, feeling, identification, intensity, contextualizations and decontextualizations, signification, power relations, imaginings and embodiments that comprise any cultural object'. ${ }^{4}$ Communication and the 'immaterial' domains of electronic media and its production are most fruitfully understood through attention to their materiality. ${ }^{5}$ So we might think of code as the object that best offers a glimpse of the material stuff that coordinates everyday life, defines the structure and operations of machines and software tools, drives the routines of logistical systems and even defines and thus controls the obligations, rights and responsibilities of individuals, organisations and institutions of governance.

But it doesn't take much digging to find that code problematises its own status as an object of analysis, and indeed troubles notions of action and agency. A slippage between code as object and act becomes most obvious in the sense of code as law. As a way of elucidating the often obscured role of computer code and internet protocols 
in the governance of human affairs, Lawrence Lessig argued in the late 1990s that 'code is never found; it is only ever made'.6 Lessig's work is worth flagging here because it emphasises the interconnections between social life, institutions of governance and technologies at the level of code in ways that move between object and act. This broad goal is taken up more critically by scholars such as Alexander Galloway in his work on protocol as a diagram of societal control, where the analysis of late capitalism must take account of the productive power of computers, software, protocol and code.7 People, corporations, states and multistate bodies codify rules, norms and accepted practice as bodies of law, but the functional codes shaping the internet, software programs, apps and devices are less obvious, more contested and have an increasing impact on human affairs and relations. The process of coding as a set of collaborative, creative, technical but also rule-defining acts and commands, becomes in this way a key object for critical analysis. Signalling the multiple threads of this critical project, David Berry notes that code needs to be approached 'as a literature, a mechanism, a spatial form (organisation), and as a repository of social norms, values, patterns and processes'. ${ }^{8}$

We wish to emphasise this double articulation in the notion of code, where code implies both object and act; a language that commands, and a set of building blocks to be manipulated through the act of coding or in the formation of protocols, software, hardware and law. ${ }^{9}$ At the heart of code lies a labour cost that is often hidden, and underpinning labour is the hidden work of code. So on the one hand, as Berry argues, there is a need to account for code's 'physicality and obduracy'; but on the other hand, we should also look to "the "code work" and "software work" that goes into making and maintaining code, the networks and relationships, and the work that goes into the final shipping product or service'.10 In addition to software and computational cultures, ${ }^{11}$ code as executable command and as field of labour is well illustrated, for instance, in contemporary work organisation and management practices. As we will discuss below, in that context code indicates the violence of the norm-or the form-while embedding a sense of negotiation and conflict into everyday management practice, and becomes apparent in the eruptions of affect to be dealt with through crisis management as the force that maintains everyday management and labour practice. 
The intersection of code and labour can seem both mysterious and intriguing. And it is often celebrated reflexively as the source of the increasing significance of computation and software to the functioning of society. This intersection becomes apparent and takes on an urgency at points of breakdown, or in those accounts of processes of software or hardware production far less systematic or organised than the end product might suggest; including, for example, revelations of exploitative global hardware production and labour practices beneath the sleek appearance of an Apple device. The uneasy and dynamic juncture of code and labour is also 'revealed'-in the sense that it is made visible as well as imagined-in 'behind the scenes' accounts of programming practices. In fact, behind the scenes, under the hood and other metaphors of surface and depth are crucial to how code is imagined today. ${ }^{12}$ Among many others, cofounder of Salon.com and technology journalist Scott Rosenberg illustrates this point through his candid narrative of the difficulties of building a complex personal information management program. In his book Dreaming in Code, Rosenberg emphasises code's duplicity and fragility:

Our businesses and banks, our elections and news media, our movies and our transportation networks, our health care and national defense, our scientific research and basic utility services-the stuff of our daily existence hangs from fragile threads of computer code. ${ }^{13}$

It is the fragility of code-software errors, bugs, viruses and other failures-that best illuminate its centrality and precarity for 'our daily existence'. We rely on its operations, and in turn it helps in myriad ways, from the micro functions of smart phones to the macro functions of traffic systems and work processes, but it quivers always under the risk of failure, the possibility of glitch or other forms of critical malfunctions. The bulk of Rosenberg's narrative is given over to the processes of production, the creative labour where 'we dream it, then we try to write it-and all hell breaks loose'.14 This illustrates Berry's point: 'Code is labour crystallised in a software form that is highly flexible and which when captured may be executed indefinitely'; it runs as an unfinished project, always in process. ${ }^{15}$ Production schedules drawn up for programmers under the auspice of project management appear ludicrous as the overall blueprint becomes either obscured by the list of unresolved bugs, or disappears into a freeform production process. Conflict emerges between people and within the layers of code, and the software itself, far from 
functioning freely and rationally, takes on a life of its own, resembling a pit of snakes to be tamed. 16

Coders come together in different environments and organisational setups, with a wide range of work processes. Programming in this way participates in its own abstraction, de-materialisation and globalisation. But as Mackenzie argues, more prototypical practices such as so-called extreme programming attempt to position coding itself as the most significant activity in software development in order to challenge certain relations of production associated with other forms of software engineering'. ${ }^{17}$ In his ethnographic observations of programmers adhering to such work practices, Mackenzie describes a communal table and inward facing computers, surrounded by fast food and soft drink detritus, and a 'build machine' at the end, working to a 'clean' and 'pure' philosophy of coding practice. As veneration of those more prototypical production practices, similar images of creative labs circulate online with a sense of knowing celebration for insiders. These are images and ideals, of course, that belie the often more traditional factory-like, hierarchical and increasingly globally outsourced practices of coding, a point made by in this issue Jussi Parikka, among others.

As a specific form of labour that many argue defines postindustrial capitalist society, in its collaborative, creative, informational and often financially unrewarded forms, coding becomes a site for both control and potential resistance. ${ }^{18}$ So many recent accounts of the process of creating code or of the collaborative labour of software production, for instance, recognise this investment. On the one hand, open source software has so often been understood as heralding a form of labour or collaboration outside traditional proprietary and financial reward systems, as well as offering a challenge to the logic of corporate labour practices and codes of intellectual property. ${ }^{19}$ Galloway notes hackers' potential to alter technology, code and protocol.20 And Hardt and Negri see in free and open source software movements a model to be mapped more broadly onto society, where accessible source code allows collaborative labour to 'create new, better social programs'. ${ }^{21}$ On the other hand, as Terranova notes, such 'free labour' also bears the cost of the passionate but financially unrewarded labour practices at the heart of coding and internet content production. ${ }^{22}$ 
Software and digital computation have come to pervade the contexts of our play, labour and creativity, ${ }^{23}$ just as the production of software and digital environments have become symbolic sites for the kinds of immaterial and affective labour that define contemporary capitalism or, as Maurizio Lazzarato famously put it, the labour 'that produces the informational and cultural content of the commodity'. ${ }^{24}$ Following the Italian autonomist tradition and the work of Hardt and Negri, Alexander Galloway and Eugene Thacker identify some of the domains in which code and labour have become entangled:

the decline of Fordist economies in the west and the rise of postindustrial information and service economies, the transnational and immigrant quality of labour forces, the global outsourcing of production in high-tech fields, the dissemination of cultural products worldwide, the growing importance of networked machines in the military and law enforcement, the use of highly coded informatics systems in commodity logistics, or the deployment of complex pharmacological systems for health therapies and management of populations. ${ }^{25}$

Many questions have been raised about the potential exploitations of digital labour within these and other entwined contexts. In 2009, for example, 'The Internet as Playground and Factory', a conference convened by artist and writer, Trebor Scholz, along with subsequent publications, probed the formation of digital economies within neoliberal markets as they are shored up by 'free labour' leading to new models of exploitation and surveillance. As Scholz explains:

The Internet has become a simple-to-join, anyone-can-play system where the sites and practices of work and play increasingly wield people as a resource for economic amelioration by a handful of oligarchic owners. ${ }^{26}$

Terms such as free, immaterial or affective labour attempt, in different ways, to capture what is at stake economically and emotionally in practices such as fandom, blogging, chat room moderation and the socio-economic exchanges within MMO games such as 'World of Warcraft'.27 This is, of course, by no means a homogenous field sharing similar methodological principles or critical projects. Indeed, one of the points of departure is the extent to which immaterial or affective labour represents opportunities for resistance to and emancipation from the normative strictures of workplace and organisational settings. ${ }^{28}$ Underpinning much of the research is the 
demand we recognise, perhaps with difficulty, that these new forms of labour operate using the protocols and ideologies of older oppressive forms of work, exploitation and alienation. Scholz conveys this oversight succinctly when he says:

casual digital labour looks merely like the expenditure of cognitive surplus, the act of being a speaker within communication systems. It doesn't feel, look, or smell like labour at all. This digital labour is much akin to those less visible, unsung forms of traditional woman's labour such as child care, housework, and surrogacy. ${ }^{29}$

Although Scholz is right to highlight these undervalued forms of feminine labour, the material differentiations between, and specificities of, these practices are not a given. Arguably, it is only recently that the affective dimension of domestic labour, such as care, has come into critical focus. As Kathi Weeks has demonstrated in her history of immaterial labour and the socialist feminist tradition, early explorations of the role of housework within capitalist modes tended to ignore affective labour as a site of political struggle. ${ }^{30}$ For Weeks, this is not so much an oversight as a reflection of the particular socio-political landscape and the urgency with which housework might be equated with, via Marxist analyses, waged labour and hence participate in the production of use-value. In this way, she explains, 'it was no doubt more difficult to grasp the relationship between caring practices and valueproduction'. 31

One trajectory for social critique along these lines comes through the work of Arlie Hochschild, whose sustained attention to 'emotion management' and 'feeling management' in the services, caring professions and cultural industries sought a revaluation of those immeasurable qualities and intensities in certain kinds of work often undertaken by women and rarely well rewarded financially. ${ }^{32}$ Re-positioning these concerns in terms of affect—as the preindividual, bodily capacity to affect and be affected-Patricia Ticineto Clough is also interested in the ways affective labour 'goes even beyond the labor of communicative and cognitive capacities in a knowledge society or information society'. ${ }^{33}$ Attending to affect across information societies, as pre-codified intensity and as technological assemblage, is helpful for understanding the vicissitudes of the contemporary experience of labour as 'precarious', and for considering the organisation as the site for the seething flow of 
intensity and affect amid management practices that seek at times to harness or pacify those forms of passion. ${ }^{34}$

To take aim at one aspect of this broad set of contexts for the interconnection between code and labour, we will elaborate briefly on the often problematic communicative environment of the organisation, in the management of internal and external relations, forces, intensities and affects. Contemporary organisations operate both on the efficiencies brought about by technological systems and corresponding communications practices (internal and external) that in large part modulate affect-in the form of vision statements, principles and protocols, or external image and reputation management-while managing efficiencies and productivity at the level of human resources, labour practices and processes. Crucial here is the increasingly invisible operation of code and 'grey literature' forms in the codification of labour practice. These are forms that Fuller and Goffey refer to as 'evil media'.35 One question here is how, within the organisation and among knowledge work and information services in particular, affect is modulated and codified, how intensity (either in the form of passion, disaffection or anger, as well as unspecified forms of organisational risk) is increasingly the target of often automated managerial techniques and technologies.

\section{—CODE AND AFFECTIVE LABOUR: THE LANGUAGES OF MANAGEMENT AND THE VIOLENCE OF FORMS}

According to Lazzarato and others, one of the most significant shifts to occur in labour markets and organisational relations during the last few decades is the move from a Fordist, bureaucratised model dependent on manual and waged labour regulated by the figure of the foreman whose key terms are routine, standard and mechanisation to the post-Fordist phase underpinned by informational and unwaged labour managed through teams, framed by ideas of flexibility, play and creativity. ${ }^{36}$ And for Lazzarato, code is crucial to these transformations since this is the means by which these new immaterial forms function at the level of both product and process. Substantial demands for skills in cybernetics and computer science, for example, are increasingly defining the 'technical and subjective-political composition of the working class'. ${ }^{37}$ If code functions as the product emerging out of, or skill required by, immaterial labour it is also vital for its replication and 
sustainability. This is because 'participative management' requires the 'cooperation and collective coordination' of its subjects. As he explains:

the subject becomes a simple relayer of codification and decodification, whose transmitted messages must be 'clear and free of ambiguity' within a communications context that has been completely normalized by management. The necessity of imposing command and the violence that goes along with it here take on a normative communicative form. ${ }^{38}$

What fissures become visible through a process that imposes command and provokes 'violence'? In this section we use Lazzarato's observations to narrow our focus and examine the role of organisational management in codifying and modulating affect. Specifically, we want to explore how management shapes, and is shaped by, articulations of desire, fear, anger, intimacy and shame. ${ }^{39}$ In one sense it seems counterintuitive to suggest that the discursive strategies of governance include the regulation or, indeed, the codification of affect through communicative practices and cultural techniques. After all, the term 'management speak' is synonymous with precisely the opposite: the flattening of affect and Don Watson's 'death sentence'.40 As one study found, 'leadership talk in practice is often banal, cliché ridden and devoid of substance'.41

However, we suggest there might be a correlation between the opacity and the ostensibly measured register of organisational communication and the ways in which bodies and emotions are regulated, controlled and configured across institutional settings. Moreover, while the voice of management communication is framed by restraint and control, managers themselves are exhorted to adopt almost ecstatic tones through the academic literature of business schools and the genre of self-help management guides. One such guide, for example, proclaims: 'let's liberate our latent passion and that of our teams! There is no better source of ... organizational and personal excellence.' 42

In other words, there is a double logic that animates the regulation of affect in the contemporary organisation. On the one hand the manager's voice, disseminated through the media of minutes, company blogs, corporate emails, policy documents, mission statements and reports, is uttered in objective and reasoned tones. The aim of this register is to produce compliant, biddable workers. As Martin Parker puts it, as a discipline, management 'seems to be increasingly constitutive of the well 
tempered liberal subject'.43 On the other hand, there is a competing discourse that wants or imagines a workplace of joy, passion and intimacy. From the same self help guide quoted above, for example, comes this advice: 'intimacy ... may be rewritten as "into me see". It is that essential insight into each other than endows any aspirations of team community with legitimacy.'44 Similarly, according to a human relations management and organisation development consultant, to achieve 'great joy in the workplace' we need to 'cherish the best moments, those moments that provide the motivation necessary for continued contribution'. She then asks, 'what motivates the motivators?' Framed by the statement 'I feel joyful when' the author provides a bullet point list of such moments: 'I hear another person's peal of laughter; I know we have staff members who feel joy at work too' and 'I walk through the company and people greet me with a smile at every turn; only a few have questions or complaints'. ${ }^{45}$ Such displays are part of what Bjerg and Staunaes identify as a 'managerial technology' of governance and organisational life. As they put it, 'affectivity is one of the precise mechanical parts that fits managerial purposes and makes governmentality work'. 46

The tension that operates between the measured tones of minutes and the hyperbolic demands of management self-help plays an important part in codifying the organisation. Critiquing the protocols governing management language occupies a key role in what is known as the field of critical management studies (CMS). Its genesis is usually traced to the work of Mats Alvesson and Hugh Willmott, set against a backdrop of increasing neoliberalism and the corporate capitalist focus of business schools.47 CMS research is disseminated through journals such as Ephemera: Theory and Politics in Organization, Human Relations, Organization Studies and Gender, Work and Organization together with annual conferences, doctoral symposia and curriculum development. Broadly, CMS seeks to intervene in the interpretive frames of management education and practice through a diverse set of empirical and theoretical methodologies and perspectives including psychoanalysis, feminism, queer theory, neo-Marxism and labour process theory, Actor Network Theory and poststructuralism. ${ }^{48}$

Once again this field does not operate as a harmonious, discrete approach; although, clearly, these trajectories share some commonalities at the level of underlying epistemologies. According to Fournier and Grey what links many of these 
perspectives is a radical 'non performativity of intent'. In other words, CMS does not seek to reproduce workplace conditions and organisational structures as do traditional management education schools. This point is best understood by recognising the different lexicons at play. As they explain 'the invocation of notions such as power, control and inequality typically betoken some forms of critical approach whilst efficiency, effectiveness and profitability do not'. ${ }^{9}$ The refusal to replicate the discourse of management practice has been attacked by those who see it as an inability to enact real political and social change within organisations since 'suspicion of performativity can quickly slip into rejection of any practice'.50 As a rejoinder to criticisms of epistemological narcissism at the expense of workplace change, some scholars have developed the notion of 'critical performativity', which recognises the possibility of an 'active and subversive intervention into management discourses and practices'. ${ }^{51}$

If Lazzarato is right and a certain violence operates as management exerts command, it is the prosaic media of organisational labour and life through which this is felt. Forms, policies, guidelines, reports, spreadsheets and minutes attempt to codify affect in very specific ways. A business guide on how to take minutes, for example, advises: 'rather than describing the discussion as heated or angry, use passionate, lively, or energetic - all of which are just as true as the negative words' ${ }^{52}$ Similarly, another such guide warns 'always keep the tone of meeting minutes impartial, respectful and professional'.53

In direct opposition to the measured language of the organisational form, however, is the anger, frustration and shame which it can often provoke. Those people suffering from dyslexia or marginalised from health care institutions, for example, regularly experience embarrassment and fear while struggling with the demands imposed by form completion. ${ }^{54}$ As an evocative illustration of the tension between the ostensibly mundane and modest requirements of bureaucratic media and its affect is a UK newspaper report headlined 'Form-filling sends Sussex teachers off sick with stress'. The article recounts that the 'demands of endless form filling' have forced 'depressed' teachers to miss 'more than 8,000 days' from school.55 Ridiculing the claims of the piece, one commenter writes: 'this is a very misleading opening to a story. Who says "form filling" is driving teachers off with stress? It makes it sound like teachers can't cope with a bit of paperwork.'56 This 
comment succinctly demonstrates how organisations operate to render invisible certain modes of institutional labour.

For the teachers in this example, the labour required seems extraneous to their 'real' job, a view endorsed by the commenter. But what affect is produced when the labour itself is codified and audited through spreadsheet media? In wide use across the international university sector, the workload model or workload control is a management tool that aims to register the various tasks of academia and, importantly, the time required for their execution.57 A 2007 UK study entitled 'The Management of Academic Workloads' reported on a set of large-scale surveys of the sector and found substantial evidence of 'unmanageable' workloads. In addition, the increasing financial and regulatory pressures on higher education demonstrated, for these authors, the need for 'institutional interventions' that could 'focus on how best to utilise people's time' since this is the 'single biggest resource available within universities'.58

References to the principles of 'equity' and 'transparency' dominate the existing literature on the regulation of academic workload allocations. ${ }^{59}$ As a university workload planning guide puts it, the 'primary purpose of a workload planning model is most commonly described as "a tool to ensure an equitable and transparent approach to allocate work activities across academic staff"'.60 Yet equally insistent are the results from a number of these surveys that academics do not experience the processes and practices of systemised workload allocation in this manner. Interview respondents frequently note it is precisely the lack of transparency that causes anxiety and stress. Moreover, a fundamental finding that seems routinely to be overlooked is that 'staff are disinclined to measure time in detail'.61 Instead, reports and guides such as these recommend 'leadership' as key to implementing workload models. As the 2007 report puts it, 'development of a broad, neutral framework is feasible; and it is suggested that a display of transformational leadership ... can help to improve transactional leadership at a local level'.62 Their use of the term 'neutral' in the context of affective labour is quixotic in its fanciful nature. As anyone with a passing knowledge of the socio-technical media of the workload model understands it is (literally) underwritten with fear, hope, desire, envy, insecurity, incomprehension and exhaustion. Responding to a recent Guardian article titled 'Academic Workload: A Model Approach' and carrying the subheading: 'A fair and 
transparent approach to workloads should benefit academics, departments and institutions', one academic writes that the:

introduction of a workload model has destroyed morale in my institution. It has pitted staff against management, and each other, at a time when we should be focussing on teaching and research ... in our place, this has been so upsetting for so many people-it has dominated the university over the past couple of years. ${ }^{63}$

As mentioned, the desire for transparency underpins the policies and practices of workload model discourse. The workload planning guide, for example, defines three criteria which ought to be met by a successful workload model. It must be 'clearly understandable', possess 'consistent application' and 'enable appropriate "visibility" of staff activities'.64 Yet as one of the studies reports, there is little agreement from those who are subjects of the workload model on what precisely transparency means or entails. Does it necessitate the wide dissemination of an individual's own workload publicly across the university? Does 'transparency' extend to the decisionmaking process behind the formulae that governs the allocations?65 Moreover, the proclamation of transparency will inevitably come up against the protocols of control and access:

All methods require control over who can update and when data can be updated. Care also needs to be taken over the security of the information that is held. Appropriate advice and guidance should be sought to ensure appropriate controls are established.66

The tension between these competing desires resonates with what Mackenzie calls the 'opacity of code'.67 That is, despite the mobilisations of the open-source movement, 'baring the code' involves a complex multiplicity of legal, cultural, technical and economic exigencies. ${ }^{68}$ In relation to the socio-technical media of the workload model, we would argue, it is the spreadsheet that becomes the site for these regimes of invisibility. While the management literature concerning the implementation of workload models finds the spreadsheet to be the dominant form of record, there is scant regard given to the legibility or otherwise of the interface.69 Studies, guides and policy documents have certainly investigated in detail how the metrics, formulae and unit of currency of the workload model are calculated but the 
question of how these forms are encountered in organisational life is rarely considered.

Likewise, in the context of popular management writing, references to the media specificity of minutes, forms, spreadsheets and reports are striking in their absence. In a sense, this is surprising given the predominance one study found of terms such as 'communication', 'information', 'agenda setting', 'process', 'systems' and 'templates' within managerial education guides. ${ }^{70}$ However, when considering the 'hyperbolic' register deployed by the genre the elision of the banal and tedious practices of everyday organisational life functions as a rhetorical strategy to manage specific articulations of affect. ${ }^{71}$ Once again, then, there is both an excess of affect and its paucity. The material circuits of organisational communication, its discourse networks of templates and spreadsheets, operate as a mode by which affect is regulated and governed. Yet there exist fissures, moments where affect irrupts in unexpected articulations.

\section{-ORganisational CRISIS: MODULATING FORCES}

In addition to this codifying work of internal management practices, the modulation and subsequent management of external forces, forces of breakdown, error, accident, disaster and crisis has long been considered vital for any large organisation. That is because, as one business manual bluntly puts it: 'Any organization-be it an international conglomerate, medium-sized manufacturing firm, local government agency, or family business-is subject to crisis. ${ }^{\prime} 72$ And any organisation operates within an increasingly globalised network of relations that render it inherently vulnerable to risk and crisis. Recent critical attention and scholarship has taken aim at the emergence of a range of crises at the base of the interdependent and multilateral flows of capital. Both in popular discourse and in media theory, networks, computer code and software systems have come to define contemporary transnationalism, but they are also the cause of a constant state of anxiety (or risk) in need of management and contingency planning. In the context of financial crises, natural disasters, global climate change, viruses, acts of terrorism, 'we are increasingly called on both to trust coded systems and to prepare for events that elude them'.73 For Mackenzie and Vurdubakis, in their introduction to the 'Codes and Codings in Crisis' special issue of Theory, Culture and Society: 'In financial 
markets, in social media, or in visual media, crisis is inscribed in code. That is, the very structure of the code, its composition, its ordering, and its mode of existence are chronically crisis-affected. ${ }^{74}$ And, as Berry points out, software code is marked by its vulnerability 'to disruptions and failure through internal contradictions, it is also threatened by the intrusion of other external disruptions and failures, for example from institutional orders'. ${ }^{75}$

Risk and crisis, particularly in an organisational setting, are misnamed as accident. Wendy Chun goes as far as to argue that 'crises are not accidental to a culture focused on safety, they are its raison d'être'. ${ }^{76}$ And this is evident in Jussi Parikka's comprehensive account of 'digital contagion' and the emergence of the 'computer virus', where the anomaly stands at the centre of the media ecology built around computation and network structures. ${ }^{77}$ Chun explains that 'crises and codes are complementary because they are both central to the emergence of what appears to be the antithesis of both automation and codes: user agency'. ${ }^{78}$ It is precisely in terms of user or worker agency that the interconnections between crisis, code and capital can be traced back to the emergence of the field of crisis management as a new part of the productivity of the capitalist organisation post World War II. Here, as a precursor to the more complex algorithmic approaches to modelling and disaster management, crisis came to be embedded within management and labour practices.

Foundational crisis management guru, Steven Fink, liked to parse the word 'crisis' as danger and opportunity through the derivative Chinese characters. Fink always thought the word 'crisis' had an 'erroneously negative connotation'.79 In his influential 1986 book Crisis Management: Planning for the Inevitable, Fink made the crucial move for management and organisational studies by relinquishing the negative in crisis. The emphasis for any organisation, for Fink, should be on 'the preparation necessary for capitalizing on crises and creating achievement out of adversity, inspiration out of humiliation, opportunity out of danger'. ${ }^{80}$ Fink urges managers and workers alike to adopt a mode of constant crisis awareness: 'you and your managers should understand that anytime you're not in a crisis, you are instead in a precrisis, or prodromal mode' ${ }^{81}$ The protocols of crisis management merge with and in many ways direct the normal operations of the organisation.

In the early 1990s Kenneth N. Myers referred to the disaster life cycle as part of an organisation's normal operations, extending into preceding phases of 
contingency planning and postcrisis evaluation and realignment. ${ }^{82}$ This is a cycle that flows through:

normal operations (the period before a disaster occurs), emergency response (the period immediately following a disaster), interim processing (a period in which temporary measures are taken to support essential functions), and restoration (when operations return to normal). ${ }^{83}$

Guth's study is itself interesting in charting the gradual integration of public relations crisis response roles and practices within the normal operations of organisational management, showing up the historical point in the mid-1990s where crisis management-and we might add affect management—shifts from the externally contracted communications professional (the public relations company) to take a central place in an organisation's management structure, embedding occupational health and safety and emergency response protocols, and strategic contingency planning. Crisis is considered the counterpart of the risk that is the natural state for any (entrepreneurial or non-profit) organisation. Organisations put capital and human resources at risk. ${ }^{84}$ There are two directions this outlook might take. In US crisis management and crisis communication literature and research, the connection between crisis and risk is framed not as how to protect people from organisational disasters-the catastrophic events that harm environments and people-but rather how to protect capital or the organisation, its managers and their reputation from the disdain, anger and rage of those who have been wronged or even hurt, within or outside the organisation. In this way organisational crisis management moves quickly through crisis communication to seek recovery and resolution, the restoration of its image and profitability.

We raise this trajectory of risk and crisis management within organisational theory and practice as concomitant to those techniques for codifying and modulating internal eruptions of affect outlined above in relation to tools such as the workload model. With the integration and routinisation of contingency planning into organisational practice comes the recognition that this ongoing 'prodromal mode' requires the management of both external and internal crises. Continuous training in occupational health and safety protocols often in automated modules is symptomatic of the dual processes of monitoring and stemming both internal and external crises. Likewise, the workload model might be understood as a technique 
for managing the ever-present potential crises of capital flow and labour productivity. The slippage between code as object and act becomes apparent at points such as these where protocol and command subsume the agency of both management and labour, working always to modulate those forces of affect at work within and outside the organisation. But code and labour run together in many ways besides, and it is the aim of this issue to consider the intricacies of some of these contexts.

\section{- Coding LABOUR SECTION}

In November 2012, Swinburne University, Melbourne, hosted CODE-A Media, Games and Art Conference. A transdisciplinary project, the conference aimed to 'consider the role of code as a simultaneously material and semiotic force that operates across the wider cultural, social and political field, with particular emphasis on media, games and art'. CODE was attended by one hundred national and international delegates and exhibiting artists, including key note speakers Jussi Parikka, Anna Munster and Christian McCrea. ${ }^{85}$ The labour of code and the codes of labour emerged as a significant conceptual theme of the conference inviting further discussion, speculation, analysis and provocation to which this special section responds.

The articles that make up the coding labour section of this issue of Cultural Studies Review consider the coupling of code and labour within three interrelated spheres of critical concern: the materiality of code in the emergence of new humancomputer assemblages; the labour of code in the design, production and use of media art, games and software; and the regulation or self-regulation of cultural practices. Each of the articles align with our section's aim to reaffirm the complexities of code for emerging fields such as software studies, and to also consider some of the ways code moves between media, software and computation, through labour into social life and global capitalism.

Jussi Parikka develops an analysis of the contested notion of cognitive capitalism by bringing together German media theory with an account of cultural technique within the context of the management of code and code work. Parikka takes a critical look at the purported shifts from a hierarchical factory model of capitalism to the horizontal networks valorised in the work of Juan Moulier Boutang 
and others, particularly around the production of software. For Parikka, 'what sustains the cognitive is a field of techniques', and so the cognitive should be examined across a range of practices, management techniques and organisational forms that happen outside the brain. Cognition and the modes of communication that enable its extension across time and space thus function as a productive force for capitalist accumulation. As a useful and provocative starting for this issue, Parikka considers Steve Jobs's exhortations that we 'break with the old habits of media consumption and techniques', and 'plan new ways of engaging with software worlds'; that is, as we design and program new technologies we must allow ourselves to be reprogrammed. Parikka also turns to the writings of Hungarian-born Palo Alto PARC Xerox computer scientist, Charles Simonyi. In the 1970s Simonyi forwarded an account of metaprogramming as an organisational schema or mode of command that sought to manage dynamic and often disconnected programming systems, languages and work processes, to standardise procedures in the name of productivity. In this organisational diagram, Parikka details the revealing materialities of both technology and labour that become central to the cognitive capital of code and coding work in ways that do not equate with the sense of fun and creativity in Boutang's account of cognitive capitalism.

Ned Rossiter explores logistics and supply chain capitalism through an account of the as yet unbuilt computer game Logistical Worlds to consider the contextsboth current and potential-in which living labour reckons with new governmental regimes of logistical control. The computer game serves as a site to test the parameters (in the technical sense) of global logistics industries and supply chains. Logistics operates here as both informational and organisational practice marking the shift from a general bureaucratisation of society to one where knowledge and labour are 'increasingly transferred to the algorithmic agency of machines and code'. With the development of sophisticated tracking systems and logistical software, the delay between labour and its measurement has been short circuited, as 'labour and performativity are captured in the real-time algorithms of code'. But in this process those more 'immaterial forces' of workers' attitudes, feelings and motivations are denied.

Remaining in the game world, and more specifically the online multiplayer world of EVE Online, Melissa de Zwart and Sal Humphreys trace the complicated 
overlap of law, rules, protocols and behavioural codes in a virtual platform designed to be a 'lawless frontier'. They describe EVE Online as a 'heterotopian space', and as the site of relentless negotiation and conflict. Its governance structure floats uneasily between the Terms of Use, End User Licence Agreement and external laws such as those relating to copyright, harassment or vilification (which add complexity because of their variation across users' jurisdictions), as well as the more diffused governance mechanisms of interplayer contracts and the 'Council of Stellar Management', a player representative body that functions as a consultative committee organised in evolving stages by players themselves. In other words, the game space operates as a 'nest of rules, code, norms and law' in constant tension with those 'disruptive practices' of marginal player conduct in which rules are bent through 'modding, griefing and cheating', for example. But the game space becomes interesting for players precisely where they can play with and against the code, between control and creativity.

It is to the materiality of media hardware and the aura of authorship in the digital text that Rowan Wilken turns his attention. Wilken probes the labour relations and management decisions surrounding the State Library of Victoria's 2001 and 2008 acquisitions of novelist Peter Carey's laptop and desktop computers on which he wrote his Booker Prize winning novel The True History of the Kelly Gang. These technological objects, including the files, email exchanges and other digital traces that constitute notes and drafts of Carey's writing, were conceived by the library as important access points to the 'creative drive or creative unconscious' of Carey, and were seen as a site through which the library would work to reposition its role as cultural exhibitor. But this repositioning work also exemplifies the contested shift to 'embrace collection digitisation as the path forward', signalling broader debates within digital humanities regarding the relations between digital data and human creativity. Creative labour, thought and authorship have always been entwined with writing technologies, as Kittler, Ong, Nietzsche, Derrida and others have explained. Wilken considers these connections through Carey's personal writing technologies at the boundaries of 'the material turn in information and media studies and the "immaterial turn" in preservation/archival studies'.

The materiality and 'work' of data can also be considered at a larger scale. Mark Coté examines the 'motility' of data within cloud-based network storage and in 
terms of Apache's open source Hadoop platform as a key tool to help states and social network proprietors such as Facebook realise the potential of 'big social data' (BSD). Big social data is conceived here as the 'social data captured by the digital human', and Coté adopts Foucault's notion of the dispositif to account for the whole heterogeneous apparatus, or assembly, within which our quotidian actions are put to use by capital in the form of BSD analytics. Coté uses the term 'data motility' to signify the movement, flow and volatility of data and its nomadic qualities and autonomous movement within the cloud-computational environment. It is in the notion of debt, following Lazzarato in particular, that Coté sees state and commercial strategies of control surrounding the everyday use of social and mobile media, in capital's imperative to become productive. BSD defines the 'endless payments we make to neoliberal digital or cognitive capitalism', the hidden cost in what we 'buy into in our social usage'.

In a deliberately provocative move, Anna Munster shifts her focus to the signaletic as an aspect of modern technicity that precedes-or supersedescodification. Examining the video art of Nam June Paik among others, and do-ityourself drone videos found on YouTube, Munster examines the ways each tests the flow of signal and signal processing as forms of transmateriality and transduction, drawing particularly on the work of Gilbert Simondon and Adrian Mackenzie. Munster's is a fitting final article for this section in its efforts to think beyond the bounds and bounding nature of code as a ubiquitous feature of contemporary digital culture. The lack of attention to signaletics, Munster argues, is strange given the significance of electronic media over the past century, and it also points to areas of experimentation and opportunity that may indeed complement our attention to code.

Anthony McCosker lectures in Media and Communications in the Faculty of Health, Arts and Design at Swinburne University, Melbourne, Australia. His research explores media affect, media technology, digital and visual cultures and social media practices and publics. He is author of Intensive Media: Aversive Affect and Visual 
Culture (2013), along with numerous book chapters and journal articles in these research areas.

Esther Milne is the Academic Director of Graduate Studies in the School of Arts, Social Sciences and Humanities at Swinburne University, Melbourne, Australia. Her research focuses on the material, legislative and affective framings of media history located within networked postal communication systems. She is the author of Letters, Postcards, Email: Technologies of Presence (2010).

\section{-NOTES}

${ }^{1}$ Adrian Mackenzie and Theo Vurdubakis, 'Codes and Codings in Crisis: Signification, Performativity and Excess', Theory, Culture and Society, vol. 28, no. 6, 2011, pp. 3-23, 5.

${ }^{2}$ Adrian Mackenzie, Cutting Code: Software and Sociality, Peter Lang, New York, 2006. A rich trajectory of software studies has begun to explore the intersections of code, technology, computation and the social. See for example: Matthew Fuller, Behind the Blip: Essays on the Culture of Software,

Autonomedia, New York, 2003; Matthew Fuller, Software Studies: A Lexicon, MIT Press, Cambridge, MA, 2008; David M. Berry, The Philosophy of Software: Code and Mediation in the Digital Age, Palgrave Macmillan, Houndmills, Basingstoke, 2011; Lev Manovich, Software Takes Command, Bloomsbury, London, 2013; Alexander Galloway, Protocol: How Control Exists after Decentralization, MIT Press, Cambridge, MA, 2004.

${ }^{3}$ See for instance Berry, The Philosophy of Software, p. 40; Mackenzie.

${ }^{4}$ Mackenzie, p. 5.

${ }^{5}$ Matthew Fuller, Media Ecologies: Materialist Energies in Art and Technoculture, MIT Press, Cambridge, MA, 2005, p. 2; Jeremy Packer and Stephen B. Crofts Wiley (eds), Communication Matters: Materialist Approaches to Media, Mobility and Networks, Routledge, London, 2012.

${ }^{6}$ Lawrence Lessig, Code and Other Laws of Cyberspace, Basic Books, New York, 1999, p. 6.

${ }^{7}$ Galloway, Protocol. David M. Berry also offers a sustained critique of the 'Free/Libre Open Source Software' (FLOSS) movement to show 'how code designates what is prescribed and what is not, what is articulated and what is silenced; how code structures our lives and our subjectivity', in his Copy, Rip, Burn: The Politics of Copyleft and Open Source, Pluto Press, London, 2008.

8 Berry, The Philosophy of Software, p. 36.

${ }^{9}$ See also Wendy Chun, Programmed Visions: Software and Memory, MIT Press, Cambridge, MA, 2011. Chun traces the emergence of software as an object or thing through processes of commodification in codes' conflation with action.

10 Berry, The Philosophy of Software, pp. 32-3. 
${ }^{11}$ As explored across the extant body of software studies scholarship and within new journals such as Computational Culture.

12 The discourse of layers - of application, transport, network, hardware and so on-becomes a recurring theme central to the operations of code and computing. See for example Galloway, Protocol and Alexander Galloway, The Interface Effect, Polity, Cambridge, UK, 2012.

${ }^{13}$ Scott Rosenberg, Dreaming in Code, Three Rivers Press, New York, 2007, p. 9.

${ }^{14}$ Rosenberg, p. 10.

15 Berry, The Philosophy of Software, p. 39.

16 Rosenberg, p. 108.

17 Mackenzie, p. 141.

18 Berry, 'Free/Libre Open Source Software'.

19 Ibid.

20 Galloway, Protocol.

21 Michael Hardt and Antonio Negri, Multitude: War and Democracy in the Age of Empire, Penguin, New York, 2004, p. 340; cited in Gabriella Coleman, Coding Freedom: The Ethics and Aesthetics of Hacking, Princeton University Press, New Jersey, 2013, p. 195.

22 Tiziana Terranova, Network Culture: Politics for the Information Age, Pluto Press, London, pp. 73-97; see also Mark Coté and Jennifer Pybus, 'Learning to Labour 2.0: MySpace and Social Networks', Ephemera: Theory and Politics in Organization, vol. 7, no. 1, 2007, pp. 88-106.

23 Trebor Scholz (ed.), Digital Labour: The Internet as Playground and Factory, Routledge, London, 2013.

${ }^{24}$ Maurizio Lazzarato, 'Immaterial Labor' in Radical Thought in Italy: A Potential Politics, eds Paolo Virno and Michael Hardt, University of Minnesota Press, Minneapolis, 1996, pp. 133-50, 133.

25 Alexander Galloway and Eugene Thacker, The Exploit: A Theory of Networks, University of Minnesota Press, Minneapolis, 2007, pp. 3-4.

${ }^{26}$ Scholz (ed.), Digital Labour, p. 1.

27 See, for example, Abigail De Kosnik, 'Fandom as Free Labor' in Digital Labor: The Internet as Playground and Factory, ed. Trebor Scholz, Routledge, London, 2013, pp. 98-111; Jodi Dean 'Whatever Blogging' in Digital Labor, ed. Sholz, pp. 127-46; Tizianna Terranova, 'Free Labor' in Digital Labor, ed. Sholz, pp. 33-57; Lisa Nakamura, 'Don't Hate the Player, Hate the Game: The Racialization of Labor in World of Warcraft' in Digital Labour, ed. Sholz, pp. 187-204.

${ }^{28}$ For example see Patricia Ticineto Clough, Greg Goldberg, Rachel Schiff, Aaron Weeks and Craig Willse Clough, 'Notes Towards a Theory of Affect-Itself', Ephemera: Theory and Politics in Organization, vol. 7, no. 1, February 2007, pp. 60-77; Emma Dowling, Rodrigo Nunes and Ben Trott, 'Immaterial and Affective Labour: Explored', Ephemera: Theory and Politics in Organization, vol. 7, no. 1, February, 2007, pp. 1-7.

${ }^{29}$ Scholz, p. 2. 
${ }^{30}$ Kathi Weeks, 'Life Within and Against Work: Affective Labor, Feminist Critique, and Post-Fordist Politics', Ephemera: Theory and Politics in Organization, vol. 7, no. 1, February 2007, p. 236. For Weeks: 'There was a tendency ... to privilege the example of housework over affective forms of domestic labour. Indeed one of the things that is so striking about the literature from a contemporary perspective was how rarely the specificities of caring labour were addressed, a tendency perhaps attributable to the feminization of the work.'

31 Ibid., p. 236.

32 Arlie R. Hochschild, The Managed Heart: Commercialization of Human Feeling, University of California Press, Berkley, 2003; Arlie R. Hochschild, The Commercialization of Intimate Life, University of California Press, Berkley, 2003; for an exploration of these arguments in relation to blogging practices see Anthony McCosker and Raya Darcy, 'Living with Cancer: Affective Labour, Self-Expression and the Utility of Blogs', Information, Communication and Society, 2013,

<http://www.tandfonline.com/doi/abs/10.1080/1369118X.2012.758303\#.UgnRspJ_Png>.

33 Patricia Ticineto Clough, 'The Digital, Labor, and Measure Beyond Biopolitics' in Digital Labour, ed. Sholz, pp. 112-26, 113. See also Clough et al., 'Notes Towards a Theory of Affect-Itself'; Paolo Virno, $A$ Grammar of the Multitude, trans. I. Bertoletti et al., Semiotext(e), New York.

${ }^{34}$ Brett Neilson and Ned Rossiter, 'From Precarity to Precariousness and Back Again: Labour, Life and Unstable Networks', Fibreculture Journal, vol. 5, 2005, <http://five.fibreculturejournal.org/fcj-022from-precarity-to-precariousness-and-back-again-labour-life-and-unstable-networks/> .

35 Matthew Fuller and Andrew Goffey, Evil Media, MIT Press, Cambridge, MA, 2012.

36 Alexander Styhre, 'Management Control in Bureaucratic and Postbureaucratic Organizations: A Lacanian Perspective', Group \& Organization Management, vol. 33, no. 6, 2008, pp. 635-56; John Roberts “The Power of the "Imaginary” in Disciplinary Processes', Organization, vol. 12, no. 5, 2005, pp. $619-42$.

37 Maurizio Lazzarato, 'Immaterial Labor' in Radical Thought in Italy: A Potential Politics, eds P. Virno and M. Hardt, University of Minnesota Press, Minneapolis, 1996, pp. 132.

38 Ibid., pp. 134-5

39 Dorthe Staunæs and Helle Bjerg, 'Self-Management Through Shame: Uniting Governmentality Studies and the Affective Turn', ephemera: theory and politics in organization, vol. 11, no. 2, 2011, pp. 138-56.

40 Don Watson, Death Sentence: The Decay of Public Language, Vintage, Sydney, 2004.

${ }^{41}$ Michaela Driver, 'The Lack of Power or the Power of Lack in Leadership as a Discursively Constructed Identity', Organization Studies, vol. 34, no. 3, 2013, p. 407.

42 Omar Khan and Paul Brown, Liberating Passion: How the World's Best Global Leaders Produce Winning Results, John Wiley, New Jersey, 2011, p. 6.

43 Martin Parker, 'Queering Management and Organization', Gender, Work \& Organization, vol. 9, no. 2, 2002, p. 161.

44 Khan and Brown, p. 30. 
45 Susan M. Heathfield 'What Brings You Joy in the Workplace? Sixteen Motivators', <http://humanresources.about.com/cs/worklifefamily/qt/Joy.htm>.

46 Bjerg and Staunaes, p. 139.

47 Mats Alvesson, and Hugh Willmott (eds), Critical Management Studies, Sage, London, 1992;

Christopher Grey and Hugh Willmott, 'Introduction', Critical Management Studies: A Reader, Oxford University Press, 2005, pp. 1-20.

48 Campbell Jones and André Spicer, 'The Sublime Object of Entrepreneurship', Organization, vol. 12, no. 2, 2005, pp. 223-46; Styhre, 'Management Control in Bureaucratic and Postbureaucratic Organizations' pp. 635-56; Driver; Saija Katila and Päivi Eriksson, 'He is a Firm, Strong-Minded and Empowering Leader, but is She? Gendered Positioning of Female and Male CEOs', Gender, Work and Organization, vol. 20, no. 1, January 2013, pp. 71-84; Karen Lee Ashcraft, 'Organized Dissonance: Feminist Bureaucracy as Hybrid Form', Academy of Management Journal, vol. 44, no. 6, 2001, pp. 1301-22; Parker, pp. 146-66; Nick Rumens, 'Working at Intimacy: Gay Men's Workplace Friendships', Gender, Work and Organization, vol. 15, no. 1, 2008, pp. 9-30; David Knights and Hugh Willmott (eds), Labour Process Theory, Macmillan, London, 1990; Paul Thompson and Chris Smith (eds), Working Life: Renewing Labour Process Analysis, Palgrave Macmillan, London, 2010; Rafael Alcadipani and John Hassard, 'Actor-Network Theory, Organizations and Critique: Towards a Politics of Organizing', Organization, vol. 17, no. 4, 2010, pp. 419-35; Franck Cochoy, 'Driving a Shopping Cart from STS to Business, and the Other Way Round: On the Introduction of Shopping Carts in American Grocery Stores (1936-1959)', Organization, vol. 16, no. 1, 2009, pp. 31-55; Campbell Jones, 'Poststructuralism in Critical Management Studies' in The Oxford Handbook of Critical Management Studies, eds Mats Alvesson, Todd Bridgman and Hugh Willmott, Oxford, Oxford University Press, 2009, pp. 76-98. 49 Valerie Fournier and Chris Grey, 'At the Critical Moment: Conditions and Prospects for Critical Management', Human Relations, vol. 53, no. 7, 2000, p. 17

50 Paul Thompson, 'Brands, Boundaries and Bandwagons: A Critical Reflection on Critical Management Studies' in Critical Realism in Action in Organisation and Management Studies, ed. S. Fleetwood and S. Ackroyd, London, Routledge, 2005, p. 60.

51 André Spicer, Mats Alvesson and Dan Kärreman, 'Critical Performativity: The Unfinished Business of Critical Management Studies', Human Relations, vol. 62, no. 4, 2009, p. 538.

$52<$ http://www.businesswritingblog.com/business_writing/2006/01/tips_for_writin.html>.

$53<$ http://www.ehow.com/how_5639076_create-effective-meeting-minutes.html>.

$54<$ http://www.4dyslexics.com/art003.htm>, <http://www.dyslexia-help.org/employmentadvice.asp $>$.

55 Neil Vowles, 'Form-filling sends Sussex teachers off sick with stress', Argus, 6 April 2011, <http: //www.theargus.co.uk/news/8956996.Form_filling_sends_Sussex_teachers_off_sick_with_stress/>. 56 'Censored', 4:44pm Wed 6 Apr 11, <http://www.theargus.co.uk/news/ 8956996.Form_filling_sends_Sussex_teachers_off_sick_with_stress/>. 
${ }^{57}$ Loughborough University, Leicestershire, UK, 2005, 'Workload agreement on the operation and control of workload' <http://www.lboro.ac.uk/services/hr/a-z/workload-agreement.html>. 58 Peter Barrett and Lucinda Barrett, The Management of Academic Workloads: Summary Report (Leadership Foundation for Higher Education Research and Development series), Leadership Foundation for Higher Education, London, 2007, p. 3.

${ }^{59}$ See for example, University of Glasgow, School of Social and Political Sciences, Workload Model, 2012, 1, <http://www.gla.ac.uk/media/media_240643_en.pdf>; The University of Melbourne, 'Principles For An Effective Academic Workload Allocation Model', 2010, 1,

<http://hr.unimelb.edu.au/_data/assets/pdf_file/0019/511426/Workload-Model-Principles.pdf.>. ${ }^{60}$ Financial Sustainability Strategy Group, Management Information Portfolio 'Fulfilling Student Expectations through Effective Planning', June 2011, The Higher Education Funding Council for England, p. 1, <https://www.hefce.ac.uk/whatwedo/lgm/trac/toolsandguidance/ managementinformationprojects/>.

61 Barrett and Barrett, p. 30.

62 Ibid.

63 Simon Perks, 'Academic Workload: A Model Approach', The Guardian, 15 April 2013,

<http://www.theguardian.com/higher-education-network/blog/2013/apr/15/academic-workloadmodelling-management>; 15 Apr 2013 8:29pm, <https://id.guardian.co.uk/profile/pichinino/public>. 64 Financial Sustainability Strategy Group, p. ii.

65 Peter Barrett and Lucinda Barrett, The Management of Academic Workloads: Improving Practice in the Sector, Final Report, University of Salford, September 2009, p. 12.

66 Financial Sustainability Strategy Group.

67 Mackenzie, p. 26.

68 Ibid., p. 17.

69 Financial Sustainability Strategy Group, p. 12.

70 Philip Hancock and Melissa Tyler, “"MOT Your Life”: Critical Management Studies and the Management of Everyday Life', Human Relations, vol. 55, no. 5, 2004, pp 619-45.

${ }^{71}$ Alexander Styhre, 'Céline and the Aesthetics of Hyperbole: Style, Points, Parataxis and other Literary Devices', Ephemera, vol. 11, no. 3, 2011, pp 259-70.

72 James R. Di Sanza, 'Crisis Communication' in Business and Professional Communication: Plans, Processes and Performance, 3rd edn, ed. Nancy Legge, Allyn and Bacon, Boston, MA, 2005, pp. 293-325, 293. The critical, sociological approach to the pairing of crisis, accident, disaster and risk (as the broad state of affairs and concomitant industry of risk management services) has been so clearly articulated by Beck, Joost van Loon and many others since. For example, Ulrich Beck, World at Risk, trans. C. Cronin, Polity, Cambridge, 2009; Joost Van Loon, Risk and Technological Culture: Towards a Sociology of Virulence, Routledge, London, 2002. 
73 Wendy Chun, 'Crisis, Crisis, Crisis, or Sovereignty and Networks', Theory, Culture and Society, vol. 28, no. 6, 2011, pp. 91-112, 92.

${ }^{74}$ Mackenzie and Vurdubakis, p. 12.

75 Berry, The Philosophy of Software, p. 42.

${ }^{76}$ Chun, 'Crisis, Crisis, Crisis, or Sovereignty and Networks', p. 92; see also Thacker and Galloway, pp. 5-

6.

77 Jussi Parikka, Digital Contagions: A Media Archaeology of Computer Viruses, Peter Lang, New York, 2007.

${ }^{78}$ Chun, 'Crisis, Crisis, Crisis, or Sovereignty and Networks', p. 92.

79 Steven Fink, Crisis Management: Planning for the Inevitable, Amacom, American Management Association, New York, 1986, p. 15.

${ }^{80}$ Fink, p. 1.

81 Fink, p. 7.

82 Kenneth N. Myres, Total Contingency Planning for Disasters: Managing Risk ... Minimizing Loss ...

Ensuring Business Continuity, John Wiley and Sons, New York, 1993.

83 David W. Guth, 'Organizational Crisis Experience and Public Relations Roles', Public Relations Review, vol. 21, no. 2, 1995, pp. 123-36, 125; Myers, pp. 7-9.

84 Robert L. Heath and H. Dan O'Hair, Handbook of Risk and Crisis Communication, Routledge, London, 2009 , p. xi.

85 CODE-A Media, Games and Art Conference was held at Swinburne University of Technology, Melbourne, Australia, 21-23 November 2012. The organising committee consisted of Esther Milne (Chair), Steven Conway, Laura Crawford, Jane Felstead, Lawson Fletcher, Dean Keep, Jenny Kennedy, Ramon Lobato, Anthony McCosker, James Meese, Aneta Podkalicka and Mike Skolnik. $<$ http://code2012.wikidot.com/>. 